\section{Seksualopplysning med slagside}

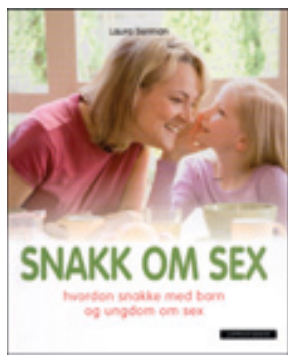

Laura Berman

\section{Snakk om sex}

Hvordan snakke med barn og unge om sex. 191 s, ill. Oslo: Cappelen Damm, 2011.

Pris NOK 329

ISBN 978-82-02-33105-4

Målgruppener foreldre som ønsker å gi barna sine god informasjon om kropp og seksualitet. Forfatteren er sexolog og har sitt eget TV-show i USA. Boken er oversatt til norsk av Irene I. Tjørve, og dr. Kjell-Olav Svendsen har vært fagkonsulent.

De sju kapitlene har overskrifter som «Snakk om kroppen», «Snakk om kjærlighetsforhold» og «Snakk om tryggere sex». Innholdet dekker et vidt spekter: anatomi og fysiologi, barns mentale og kroppslige utvikling, kroppsbilde, holdninger, seksuell legning, prevensjon, kjønnssykdommer, og påvirkning fra mediene. Det er tegninger og plansjer over kroppen, indre og ytre kjønnsorganer, menstruasjonssyklus etc.

Det er mye om barns og unges psykologi, og hva slags informasjon de er i stand til å håndtere $\mathrm{i}$ ulike faser, men en del av anbefalingene er noe underlige. Det er neppe mange norske foreldre som vil fortelle niåringen sin om kjønnssykdommer, eller 12-åringen om onani. Jeg tror også de færreste vil kjøpe klitorisstimulator til tenåringsdatteren sin, som er blant forslagene fra forfatteren.

I andre kapitler er tonen mer formanende, for ikke å si prippen: Tenåringer bør ikke få lukke døren til rommet sitt når de har kjæresten på besøk, og man bør forby ungdommer å høre på sangtekster med «eksplisitt seksuelt innhold» fordi det visstnok gjør at de «oftere tar initiativ til samleie». Liknende paradokser finnes flere steder i teksten, og er kanskje et uttrykk for at det amerikanske samfunnet har et ganske dobbelt forhold til sex.

Ikke all faktainformasjonen er helt etterrettelig. Listen over prevensjonsmidler er mangelfull, og informasjonen om kjønnssykdommer er ikke tilstrekkelig tilpasset norske forhold. Det henvises en del til tall og forskning, men nesten bare om amerikanske forhold.

På slutten er det en liste over ressurser, organisasjoner og nettsteder, og forslag til videre lesning både for barn og voksne. Denne listen består utelukkende av engelskspråklige kilder, og referanser til amerikanske nettsteder. Til og med de anbefalte barnebøkene er engelskspråklige. Her har forlaget virkelig forsømt seg. Når boken er myntet på vanlige norske familier, burde de tatt seg bryet med å finne relevante norske ressurser.

Boken bærer generelt preg av å være oversatt direkte, uten tilpasning til den norske virkeligheten.

Jeg synes det er vanskelig å anbefale den, selv om den også har sine gode sider.

\section{Pernille Nylehn}

Krokeidesenteret avdeling Nærland Nærbø

\section{Alt de fleste bør vite om inflammatorisk tarmsykdom}

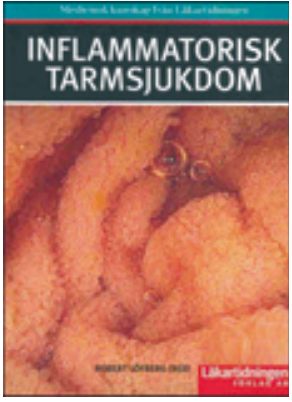

\author{
Robert Löfberg, red. \\ Inflammatorisk tarmsjukdom
}

128 s, tab, ill. Stockholm: Läkartidningen Förlag, 2010. Pris SEK 210

ISBN 978-91-978805-0-3

Våre svenske kolleger har i den lille boken Inflammatorisk tarmsjukdom laget en svært nyttig og lærerik innføring om alle aspekter ved denne sykdomsgruppen (inflammatory bowel disease, IBD). Den primære målgruppen er leger som arbeider innen medisinsk og kirurgisk gastroenterologi, men boken kan leses med stort utbytte av både sykepleiere som arbeider med denne sykdomsgruppen og den interesserte allmennlege. For utdanningskandidater innen gastroenterologi kan den anbefales som kjernepensum og må leses fra perm til perm.

Utdanningskandidatene har nok lite tid til å lese, men boken er så god at den bør være med $\mathrm{i}$ den daglige håndtering av pasientene. Den er i pocketformat og går lett ned i en legefrakklomme.

Inflammatorisk tarmsykdom er blitt et stort folkehelseproblem. Det er ingen tvil om at lidelsene ulcerøs kolitt og Crohns sykdom øker i både insidens og prevalens. Inkludert pasienter med mikroskopisk kolitt rammes ca. 0,5-1\%. Det betyr at de fleste leger møter pasienter med disse sykdommene.

Lidelsene inntar en viktig plass innen vårt moderne helsevesen ikke minst også fordi vi i dag har fått effektive medisiner. AntiTNF-hemmerne setter krav til behandlerne om riktig utvelgelse av hvilke pasienter som skal ha disse dyre medisinene. Kostnadene forbundet med slik dyr behandling bidrar til økt oppmerksomhet rundt inflammatorisk tarmsykdom, siden legemiddelindustrien naturlig nok arbeider aktivt for å selge sine preparater.

I bokens ti kapitler får man en meget god innføring i moderne patogenese, diagnostikk og behandling. Pasientene har et stort spektrum av sykdomsmanifestasjoner, og leserne får god innføring i hvordan man skal bedømme alvorlighetsgrad og prognose.

I hvert fall to tidsaktuelle temaer blir tatt opp. Det ene relaterer seg til nytten av regelmessig koloskopiovervåking av ulcerøs kolitt. Boken oppsummerer det manglende kunnskapsgrunnlaget for slik praksis, men konkluderer slik flere av oss gjør, nemlig at koloskopikontroller bør inngå i et aktivt oppfølgingsopplegg for pasienter i risikogrupper.

Det andre viktige temaet er høyaktuelt. Svenskene har et aktivt, nasjonalt pasientregister (Swibreg), der et 50-talls klinikker er med og der data på rundt 10000 pasienter legges inn. Den enkelte behandler kan trekke ut data på sine egne pasienter inkludert skopidata og medikamentbruk. Vi imponeres stadig over all kunnskap svenskene er i stand til å trekke ut av sine registre. Vårt håp er at vi kan etablere slike registre også i Norge. Det har så langt ikke vist seg enkelt. Ikke minst møter vi ofte en særnorsk skepsis til registre.

Er da boken komplett? Ikke helt. Det er interessant å se at man ikke har funnet plass til en eneste referanse til norske publikasjoner. Den største feilen med boken er nok imidlertid at vi ikke har skrevet den selv her i Norge.

Knut E.A. Lundin

Gastro undersøkelse

Avdeling for transplantasjonsmedisin

Oslo universitetssykehus, Rikshospitalet 